\title{
Analisis Penggunaan Aplikasi Daring oleh Dosen Program Studi Pendidikan Biologi Universitas Sulawesi Barat selama Pandemi Covid-19
}

\author{
M. Irfan*, Ariandi \\ Pendidikan Biologi, Universitas Sulawesi Barat, Indonesia \\ *irfan.razak@unsulbar.ac.id
}

\begin{abstract}
Abstrak
Penelitian ini bertujuan untuk mempersentasekan berbagai aplikasi media pembelajaran daring yang digunakan oleh dosen dalam pembelajaran daring selama pandemi Covid-19. Responden terdiri dari semua dosen program studi Pendidikan Biologi Universitas Sulawesi Barat yang aktif mengajar pada semester genap 2019/2020. Metode pengumpulan data yang digunakan adalah metode data primer dengan menggunakan kuisioner online. Hasil kuisioner yang disebarkan kepada responden dianalisis secara statistic deskriptif untuk mengetahui persentase penggunaan aplikasi pembelajaran. Hasil penelitian mengungkapkan bahwa dosen pada program studi Pendidikan Biologi Universitas Sulawesi Barat menggunakan WhatsApp Group 83,3\%, Google Classroom 83,3\%, ZOOM Cloud Meetings 66,7\%, E-Mail 66,7\%, Youtube 41,7\%, Quizizz 25\%, Mentimeter 8,3\%, dan Google Formulir $8,3 \%$ dalam proses pembelajaran daring. Dalam pembelajarannya dosen menggunakan lebih dari satu aplikasi. Hasil penelitian ini dapat menjadi bahan evaluasi terhadap program studi pendidikan Biologi Universitas Sulawesi Barat dalam meningkatkan kualitas pembelajaran daring di masa yang akan datang.
\end{abstract}

Kata kunci: aplikasi daring, pembelajaran.

Dikirim: 24 Desember 2020

Direvisi: 02 Januari 2021

Diterima: 05 Januari 2021

\section{Identitas Artikel:}

Irfan, M., \& Ariandi, A. (2021). Analisis Penggunaan Aplikasi Daring oleh Dosen Program Studi Pendidikan Biologi Universitas Sulawesi Barat selama Pandemi Covid-19. Jurnal Ilmu Pendidikan (JIP) STKIP Kusuma Negara, 12(2), 139-144.

\section{PENDAHULUAN}

Pandemi Covid-19 yang melanda dunia termasuk Indonesia membuat hampir seluruh aktifitas kehidupan berubah. Aspek pendidikan ikut terpengaruh terutama pada kegiatan proses belajar mengajar. Berbagai kebijakan dikeluarkan oleh pemerintah termasuk oleh Rektor Universitas Sulawesi Barat melalui surat edaran Nomor 197/UN55/HK/2020 dan Nomor 199/UN55/KP/2020 agar proses akademik dilakukan secara daring. Ini bertujuan agar pembelajaran dapat tetap berjalan serta tetap menjaga kesehatan, keamanan dan kesejahteraan di masa pandemi Covid-19 (Chick dkk., 2020).

Kuliah daring sebagai salah satu solusi pembelajaran di masa pandemi Covid19 ini merebak, dianggap cara yang terbaik untuk memutus mata rantai penyebaran virus ini. Kuliah daring memberikan pembelajaran jarak jauh dimana bahan kuliah yang diberikan oleh dosen melalui software (perangkat lunak gadget) tentu akan memudahkan bagi mahasiwa untuk tetap mendapatkan perkuliahan tanpa tatap muka. Pilihan ini harus diambil untuk melakukan tindakan pencegahan dan mitigasi yang efektif atas wabah yang kini telah menjadi pandemi global, di antara kebijakan 
yang diambil ialah menonaktifkan kegiatan perkuliahan di lingkungan kampus serta melakukan karantina mandiri mahasiswa, dosen, dan tenaga kependidikan, karyawan lainnya dan termasuk tidak melakukan pertemuan tetapi melakukan perkuliahan dan bimbingan secara daring.

Pembelajaran daring yang dilakukan selama masa pandemi tentunya amat bergantung pada ketersediaan sarana dan prasarana online. Peran teknologi sangat penting untuk memfasilitasi dalam interaksi, berkomunikasi serta penyajian materi agar proses pembelajaran berjalan dengan baik (Thoms \& Eryilmaz, 2014). Oleh karena itu penting sekali memanfaatkan teknologi dengan semaksimal mungkin. Untuk mempermudah komunikasi antara pendidik dengan peserta didik maka peran dari media pembelajaran sangat dibutuhkan (Borisova dkk., 2016). Namun jika tidak dimanfaatkan dengan baik tentunya hanya akan dapat mengakibatkan tidak terlaksananya pembelajaran dengan efektif.

Media pembelajaran merupakan gabungan antara bahan belajar dengan alat belajar dan merupakan bagian dari sumber belajar untuk dijadikan sebagai penyampai pesan dan informasi dalam pembelajaran (Muhson, 2010). Agar tujuan pembelajaran dapat tercapai secara maksimal serta meningkatkan efektivitas hasil pencapaian (Dewi, Murtinugraha \& Arthur, 2018). Selain itu, media pembelajaran juga dapat digunakan untuk meningkatkan proses dan hasil belajar dalam pembelajaran (Ayu, Arthur \& Neolaka, 2019). Pemanfatan dan perancangan media pembelajaran dengan baik akan membantu peserta didik dalam memahami materi pembelajaran.

Selama ini, pembelajaran daring sudah diterapkan oleh pendidik sebelum adanya kebijakan distance learning, hanya saja lebih cenderung pada bentuk penugasan via aplikasi (Syarifudin, 2020). Adanya kebijakan distance learning membuat proses pembelajaran sepenuhnya menjadi daring. Dalam pembelajaran daring, media pembelajaran yang dapat digunakan sangat beragam. Berbagai aplikasi online baik yang berbayar maupun yang gratis dapat diakses oleh dosen dan mahasiswa. Penggunaan aplikasi pembelajaran ini diharapkan dapat mempermudah jalannya proses pembelajaran sehingga tujuan pembelajaran dapat tercapai.

Aplikasi pembelajaran daring merupakan solusi bagi mahasiswa dalam proses pembelajaran yang tanpa dibatasi oleh ruang dan waktu yang pada sisi lain mahasiswa dituntut untuk mempelajari banyak materi dan mengerjakan tugas yang bertumpuk dari dosen. Dengan prinsip fleksibel, mahasiswa mendapatkan materi dan informasi terbaru bahkan bisa jadi informasi yang diperoleh mahasiswa melebihi dosen karena di era sekarang ini informasi sangat mudah diperoleh siapa saja. Beberapa aplikasi yang dapat membantu terlaksananya kegiatan perkuliahan secara daring, di antaranya ada WhatsApp Grup, Zoom, Edmodo, Surat Elektronik, Google Classroom, Schoology, dan lain sebagainya (Septiani \& Setyowati, 2020).

Pengertian Hybrid learning adalah model pembelajaran yang mengintegrasikan inovasi dan kemajuan teknologi melalui system online learning dengan interaksi dan partisipasi dari model pembelajaran tradisional. Kaye (dalam Hendrayati \& Pamungkas, 2013). Dengan demikian hybrid learning merupakan perpaduan antara pembelajaran dalam jaringan dan luar jaringan, perkuliahan sebagian dilakukan di kelas sebagian dilakukan melalui online.

Karakterisktik kuliah daring yang berbeda dengan pembelajaran di kelas (luring) memerlukan strategi khusus dalam menyediakan sarana komunikasi atau 
interaksi baik antara mahasiswa dengan dosen maupun antar mahasiswa itu sendiri. Secara umum ada dua jenis komunikasi yang digunakan yaitu komunikasi sinkron dan asinkron. Beberapa saluran yang dipergunakan dalam komunikasi sinkron antara lain chat dan video conference. Sedangkan pada bentuk asinkron dapat berupa LMS (Learning Management System). Pemilihan bentuk pembelajaran dan aplikasi yang digunakan tentu mempertimbangkan berbagai aspek baik dari pendidik maupun peserta didik sehingga tujuan dari pembelajaran dapat tercapai.

Berdasarkan hal tersebut di atas, penulis melakukan penelitan tentang penggunaan aplikasi pembelajaran daring oleh dosen pendidikan biologi Universitas Sulawesi Barat selama pandemi Covid-19. Penelitian ini bertujuan untuk mempersentasekan berbagai aplikasi media pembelajaran daring yang digunakan dalam pembelajaran daring.

\section{METODE PENELITIAN}

Penelitian ini merupakan penelitian deskriptif kuantitatif dengan menggunakan metode survey yang dilakukan secara online. Pengumpulan data primer dalam penelitian ini dilakukan dengan menyebarkan kuesioner secara online kepada 12 orang responden (dosen program studi penidikan biologi Universitas Sulawesi Barat yang aktif mengajar pada semester genap tahun ajaran 2019/2020). Jenis pertanyaan yang digunakan adalah pertanyaan tertutup dimana responden dapat memilih lebih dari satu pilihan jawaban. Analisis data dalam penelitian ini menggunakan satistik deskriptif dengan mencari persentase dari tiap aplikasi yang digunakan oleh responden.

\section{HASIL DAN PEMBAHASAN}

Pembelajaran dengan memanfaatkan berbagai aplikasi atau media daring telah dilakukan oleh dosen selama masa pandemi Covid-19. Hasil yang diperoleh dapat dilihat pada Gambar 1.

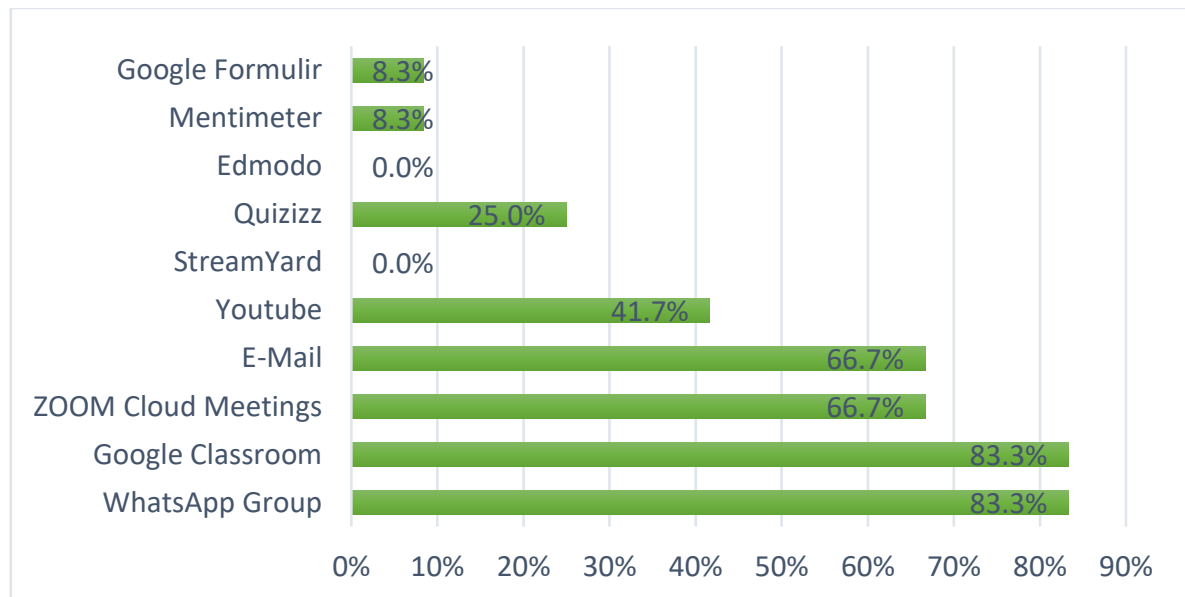

Gambar 1. Grafik Penggunaan aplikasi pembelajaran daring

Dari grafik terlihat bahwa penggunaan aplikasi WhatsApp Group dan Google Classroom memiliki persentase tertinggi 83,3\%. Hal ini berarti hampir seluruh dosen yang mengajar secara daring pada program studi pendidikan biologi 
menggunakan aplikasi WhatsApp Group dan Google Classrom. Kedua aplikasi ini memang cukup popular dan tergolong mudah dalam pengaplikasiannya serta dapat digunakan dalam kondisi jaringan 3G saja. Berbeda dengan beberapa aplikasi lain yang memerlukan koneksi 4G (kecepatan yang tinggi) untuk digunakan.

Proses pembelajaran daring pada program studi pendidikan Biologi Universitas Sulwesi Barat bukan tanpa masalah atau kendala. Kondisi wilayah Sulawesi Barat yang secara umum belum didukung oleh layanan internet yang stabil, kondisi mahasiswa yang masih belum terbiasa dengan pembelajaran daring hingga pada ketersediaan sarana prasarana pembelajaran secara daring. Terdapat beberapa masalah atau kendala yang dihadapi peserta didik pada pelaksanaan pembelajaran jarak jauh ini, seperti biaya, motivasi belajar, layanan, umpan balik, kurangnya pengalaman serta kebiasaan (Attri, 2012). Kendala lain yang dihadapi peserta didik adalah kekurangaktifan mengikuti pembelajaran, keterbatasan fasilitas pendukung dan akses jaringan internet (Asmuni, 2020). Oleh karena itu, dosen dalam menentukan penggunaan aplikasi pembelajaran daring sangat mempertimbangkan kondisi mahasiswa. Hal ini yang mendasari kebanyakan pembelajaran daring yang dilakukan oleh dosen pendidikan Biologi Universitas Sulawesi Barat menggunakan aplikasi WA Group dan Google Classroom.

Google Classroom yang ditawarkan oleh G-Suite for Education telah banyak digunakan oleh pengguna internet dikarenakan manfaatnya yang sangat besar. Dari sisi efisiensi kertas, fleksibilitas pengguna, tampilan yang simpel dan menarik, serta proses organisasi tugas oleh pengajar/instruktur yang relatif mudah dilakukan menjadi alasan mendasar pengguna memanfaatkan platform ini. Keuntungan lainnya ialah terdapat beberapa fitur yang ditawarkan sangat familiar oleh pengguna karena platform ini dikembangkan oleh google sendiri dan terintegrasi dengan aplikasi lainnya yang mendukung pembelajaran daring. Terdapat berbagai macam fitur unggulan yang ditawarkan oleh platform pembelajaran google classroom.

WhatsApp merupakan aplikasi pada smartphone yang keberadaanya saat ini sangat penting. Aplikasi komunikasi ini menjadi salah satu aplikasi komunikasi yang paling panyak digunakan saat ini. Dalam kondisi pembelajaran daring ini, tentunya aplikasi ini cukup popular dan mudah untuk digunakan sehingga hampir setiap dosen menggunakan aplikasi tersebut dalam pembelajaran daring. Pembelajaran dengan menggunakan aplikasi WA Group ini dapat dikatakan mudah dipahami atau diterapkan oleh mahasiswa karena selama ini mereka lebih sering menggunakan aplikasi ini (Septiani \& Setyowati, 2020).

E-Learning merupakan sebuah proses pembelajaran berbasis elektronik yang diakses secara online (Weni \& Isnani, 2016). Tujuan penggunaan e-learning pada pembelajaran daring adalah untuk meningkatkan penguasaan terhadap materi pembelajaran, meningkatkan interaksi antar peserta didik kepada pendidik serta memudahkan pada proses pembelajaran (Darmayanti, Setiani \&0Oetojo, 2007). Sehingga pembelajaran daring dapat berjalan efektif pada masa pandemi ini.

Pengembangan e-Learning, aplikasi google classroom sebagai media pembelajaran dalam masa pandemi dinilai sangat baik karena penggunaannya efektif serta efesian dan dapat dilakukan kapan dan di mana saja, praktis untuk digunakan, dan dapat meningkatkan hasil belajar (Subandi dkk., 2018). Namun dalam penggunaan google classroom harus diimbangi dan disesuaikan dengan koneksi internet yang baik, hal ini juga menjadi permasalahan jika terdapat keterlambatan dalam pengumpulan tugas karena koneksi yang lambat (Fauzan \& 
Arifin, 2019). Oleh Karena itu dalam penggunaannya sebaiknya disesuaikan dengan kesesuaian tingkat pembelajaran, kualitas pembelajaran serta intensitas dan waktu.

Pembelajaran jarak jauh dinilai tidak lebih baik dari pembelajaran yang dilakukan secara langsung atau tatap muka (Fojtík, 2018). Kurangnya interaksi yang efektif, minimnya pengorganisasian merupakan salah satu yang menjadi kendala pembelajaran jarak jauh, pembelajaran jarak jauh yang efektif tentu harus didukung dengan konten yang diberikan, fasilitas koneksi internet serta perhatian dan ketersediaan yang cukup besar (Buselic, 2012). Oleh karenanya penggunaan media pembelajaran dalam penerapannya mempengaruhi pembelajaran dan pemikiran yang sedang terjadi (King dkk., 2001).

Penggunaan media pembelajaran yang tidak interaktif, tidak menarik akan membuat peserta didik sulit meningkatkan motivasi belajarnya, maka media pembelajaran yang digunakan harus interaktif serta menarik untuk menghasilkan prestasi peserta didik yang baik (Handhika, 2012). Yang menjadi perhatian khusus dalam pelaksanaan pembelajaran jarak jauh, seperti pada daerah terpencil atau daerah yang tidak mendapat koneksi internet dan terbatasnya kepemilikan teknologi pasti menjadi kendala besar karena pendidik serta sekolah tidak memiliki fasilitas serta sarana yang memadai untuk proses pembelajaran jarak jauh (Basilaia \& Kvavadze, 2020). Oleh karena itu penentuan media pembelajaran sangat berpengaruh terhadap pembelajaran.

\section{KESIMPULAN}

Aplikasi pembelajaran daring yang digunakan oleh Dosen Program Studi Pendidikan Biologi Universitas Sulawesi Barat berdasarkan persentasenya adalah WhatsApp Group 83,3\%, Google Classroom 83,3\%, ZOOM Cloud Meetings 66,7\%, E-Mail 66,7\%, Youtube 41,7\%, Quizizz 25\%, Mentimeter 8,3\%, dan Google Formulir 8,3\%. Dalam pembelajarannya dosen menggunakan lebih dari satu aplikasi.

\section{REFERENSI}

Asmuni. (2020). Problematika Pembelajaran Daring di Masa Pandemi Covid-19 dan Solusi Pemecahannya. Jurnal Paedagogy: Jurnal Penelitian dan Pengembangan Pendidikan, 7(4), 281-288.

Attri, A. K. (2012). Distance Education: Problems and Solutions. International journal of behavioral social and movement sciences, 1(4), 42-58.

Ayu, N. R., Arthur, R., \& Neolaka, A. (2019). Pengembangan Media Pembelajaran Berbasis Komik Pada Konstruksi Bangunan 1. Jurnal Pensil, 8(1), 40-46.

Basilaia,0G.,0\& Kvavadze,0D.0(2020).0TransitionOto0Online EducationOin Schools during a SARS-CoV-20CoronavirusO(COVID19) Pandemic in Georgia. 5(4), 1-9.

Borisova, O. V., Vasbieva, D. G., Malykh, N. I., Vasnev, S. A., \& Bírová, J. (2016). Problem of Using Innovative Teaching Methods for Distance Learning Students. Mathematics

Buselic, M. (2012). Distance Learning - concepts and contributions. Oeconomica Jadertina, 1, 23-34. 
Chick, R. C., Clifton, G. T., Peace, K. M., Propper, B. W., Hale, D. F., Alseidi, A. A., \& Vreeland, T. J. (2020). Using Technology to Maintain the Education of Residents During the COVID-19 Pandemic. Journal of Surgical Education, 14.

Darmayanti,0T., Setiani,0M.0Y.,0\&0Oetojo,0B.0(2007). E-Learning Pada Pendidikan Jarak Jauh: Konsep yang Mengubah Metode Pembelajaran Di Perguruan Tinggi Di Indonesia. Jurnal Pendidikan Terbuka Dan Jarak Jauh, 8(2), 99-113.

Dewi, N., Murtinugraha, R. E., \& Arthur, R. (2018). Pengembangan Media Pembelajaran Interaktif Pada Mata Kuliah Teori Dan Praktik

Fauzan, \& Arifin, F. (2019). The Effectiveness of Google Classroom Media on the Students' Learning Outcomes of Madrasah Ibtidaiyah Teacher Education Department. Jurnal Pendidikan Guru MI, 6(2), 271-285.

Fojtík, R. (2018). Problems of Distance Education. International Journal of Information and Communication Technologies in Education, 7(1), 14-23.

Hendrayati, H., \& Pamungkas, B. (2013). Implementasi Model Hybrid Learning Pada Proses Pembelajaran Mata Kuliah Statistika II Di Prodi Manajemen FPEB UPI. Jurnal Penelitian Pendidikan, 13(2), 18--184.

Handhika, J. (2012). Efektivitas Media Pembelajaran IM3 Ditinjau Dari Motivasi Belajar. Jurnal Pendidikan IPA Indonesia, 1(2), 109-114.

King, F. B., Young, M.F., Drivere-Richmond, K., \& Schrader, P. G. (2001). Defining Distance Learning and Distance Education.01-14.

Muhson, A. (2010). Pengembangan Media Pembelajaran Berbasis Teknologi Informasi. Jurnal Pendidikan Akuntansi Indonesia, 8(2), 1-10.

Septiani, E., \& Setyowati, L. (2020). Penggunaan Media Pembelajaran Secara Daring Terhadap Pemahaman Belajar Mahasiswa. Prosiding Seminar Nasional Pascasarjana Universitas Negeri Jakarta. 121-128.

Subandi, S., Choirudin, C., Mahmudi, M., \& Nizaruddin, N. (2018). Building Interactive Communication with Google Classroom. International Journal of Engineering \& Technology, 7(2.13), 460-463.

Syarifudin, A. S. (2020). Implementasi Pembelajaran Daring Untuk Meningkatkan Mutu Pendidikan Sebagai Dampak Diterapkannya Social Distancing. Metalingua: Jurnal Pendidikan Bahasa dan Sastra Indonesia. 5(1), 31-34.

Thoms, B., \& Eryilmaz, E. (2014). How media choice affects learner interactions in distance learning classes. Computers \& Education, 75, 112-126.

Weni, D. M., \& Isnani, G. (2016). Meningkatkan Hasil Belajar Siswa dengan Pengembangan Media Pembelajaran. Jurnal Pendidikan Bisnis Dan Manajemen, 2(2), 114-123. 